Images in ...

\title{
Multiple cerebral gaseous emboli in an infant with fulminant necrotising enterocolitis
}

\author{
Anna E Morris, Shreela Pauliah, Alan M Groves, Merran A Thomson, A David Edwards \\ Neonatal Intensive Care Unit, Queen Charlotte's and Chelsea Hospital, London, UK
}

Correspondence to Alan M Groves, alan.groves@csc.mrc.ac.uk

\section{DESCRIPTION}

An ex-preterm infant collapsed acutely with abdominal distension, bradycardia and desaturation. Urgent echocardiogram to exclude pericardial tamponade revealed multiple, highly echogenic, foci in all four, but particularly the rightsided, cardiac chambers (video 1). Cranial ultrasound revealed multiple echogenic foci throughout the cerebral arterial vasculature, following paths of the anterior cerebral and pericallosal arteries (video 2).

Video 1 Apical four-chamber echocardiogram demonstrates highly echogenic foci in all four cardiac chambers. bcr.09.2008.0928v1

Video 2 Midline sagittal cranial ultrasound view demonstrates gas emboli following paths of anterior cerebral and pericallosal arteries. bcr.09.2008.0928v2

Abdominal x-ray subsequently showed intramural and portal venous gas, confirming a diagnosis of necrotising enterocolitis (NEC). Intravascular gas appears to have originated from the bowel wall - there was no pulmonary air leak, and iatrogenic introduction of air was excluded by visually checking all intravenous lines. In the preterm infant gas from the bowel wall and portal vein can reach the right atrium via a patent ductus venosus. From the right atrium emboli can reach the systemic arterial circulation via the foramen ovale, ductus arteriosus or intrapulmonary shunting.
Multiple gas emboli in the cerebral microvasculature may cause significant tissue damage, both from vascular obstruction-induced ischaemia and via intense activation of prothrombotic and proinflammatory cascades. ${ }^{1}$

Episodes of NEC in preterm infants are associated with adverse neurodevelopmental outcome, and patterns of preterm brain injury are known to be secondary to ischaemic and inflammatory mechanisms. ${ }^{2}$

Whereas cerebral gas emboli are unlikely to be a dominant mechanism of cerebral injury in NEC, gas in the portal vein may be underdiagnosed when relying on plain radiograph alone. ${ }^{3}$ Therefore, we present this infant with torrential cerebral gas emboli to stimulate discussion of this potential cause of cerebral injury.

Competing interests None.

Patient consent Obtained.

\section{REFERENCES}

1. van Hulst RA Klein J, Lachmann B. Gas embolism: pathophysiology and treatment. Clin Physiol Funct Imaging 2003;23:237-46.

2. Volpe JJ. Neurobiology of periventricular leukomalacia in the premature infant. Pediatr Res 2001;50:553-62.

3. Merritt CR Goldsmith JP, Sharp MJ. Sonographic detection of portal venous gas in infants with necrotizing enterocolitis. AJR Am J Roentgenol 1984;143:1059-62.

This pdf has been created automatically from the final edited text and images.

Copyright 2010 BMJ Publishing Group. All rights reserved. For permission to reuse any of this content visit http://group.bmj.com/group/rights-licensing/permissions.

BMJ Case Report Fellows may re-use this article for personal use and teaching without any further permission.

Please cite this article as follows (you will need to access the article online to obtain the date of publication).

Morris AE, Pauliah S, Groves A, Thomsan MA, Edwarda AD. Multiple cerebral gaseous emboli in an infant with fulminant necrotising enterocolitis. BMJ Case Reports 2010;10.1136/bcr.09.2008.0928, date of publication

Become a Fellow of BMJ Case Reports today and you can:

Submit as many cases as you like

Enjoy fast sympathetic peer review and rapid publication of accepted articles

- Access all the published articles

Re-use any of the published material for personal use and teaching without further permission

For information on Institutional Fellowships contact consortiasales@bmjgroup.com

Visit casereports.bmj.com for more articles like this and to become a Fellow 